\title{
W TE GRY WIĘŹNIOWIE NIE GRAJĄ. INSTYTUCJE RZECZYWISTEJ SUBKULTURY WIĘZIENNEJ ŁAGODZĄCE KONFLIKT I PRZEMOC W KONTRAŚCIE DO EKSPERYMENTU ZIMBARDO ${ }^{1}$
}

\author{
Marek M. Kamiński** \\ University of California
}

Streszczenie: W subkulturze więziennej wyewoluowaty spontanicznie nieformalne instytucje tagodzace poziom przemocy i potencjalne konfrontacje pomiędzy osadzonymi. Najpierw świeżacy (nowi więźniowie) poddawani sa testom inicjacyjnym, które staraja się zmierzyć ich sztywność (dzielność) i cwancyk (inteligencje) oraz przypisać do odpowiedniej grupy subkulturowej. Członkostwo w grupie grypsujących sygnalizuje sztywność więźniów i zniechęca do walki między grypsujacymi lub stawiania oporu przez członków niższych grup. Doświadczeni więźniowie doskonala erystykę w ramach więziennej bajery (slangu), która pozwala zamieniać rzeczywiste konflikty na pojedynki słowne, korzystaja z nieformalnego arbitrażu i uczq się pozorowania agresji wobec świeżaków. Wszyscy więźniowie staraja się dotaczyć do koalicji obronnych. Osadzeni dokonuja też spektakularnych samouszkodzeń zgodnie z tajnymi procedurami, pozorując desperację, a $w$ rzeczywistości minimalizując uszczerbek na zdrowiu i starając sie uzyskać pewne korzyści od prokuratora lub wtadz więziennych. Zebrany materiat empiryczny pochodzi $z$ aresztów śledczych na Rakowieckiej i w Biatołęce, gdzie autor spędzit pięć miesięcy w 1985 roku jako więzień polityczny.

Słowa kluczowe: Chicken, Cykor, Polska, areszt, subkultura więzienna, teoria gier, przemoc, eksperyment Zimbardo.

1 Niniejszy artykuł jest rozszerzoną wersją artykułu Kaminski (2021), który został wydrukowany w ramach licencji Creative Commons BY 4.0 pozwalającej na nieograniczony przedruk i dystrybucję w dowolnym medium pod warunkiem zacytowania źródła. Tłumaczenie Barbara Kaminski. Następujące osoby podzieliły się ze mną cennymi uwagami po przeczytaniu tekstu: Dan D'Amico, Harry David, Barbara Kaminski, Whitney Lake, Marcin Malawski, Adam Martin, David Skarbek, Donald Woodward oraz uczestnicy kolokwium „Sociality and Austrian Economics" na Uniwersytecie Texas Tech w Lubbock.

* Marek M. Kamiński, Instytut Matematyki Behawioralnej i Wydział Nauk Politycznych, University of California, 3151 Social Science Plaza, Irvine, CA 92697-5100, USA, ORCID: 0000-0003-3997-0541, tel. 9498242744, e-mail: marek.kaminski@uci.edu, KOD JEL: D72. 


\title{
PRISONERS DO NOT PLAY THESE GAMES. ACTUAL PRISON SUBCULTURE INSTITUTIONS MITIGATING CONFLICT AND VIOLENCE IN CONTRAST TO ZIMBARDO'S EXPERIMENT
}

\begin{abstract}
In the prison subculture, informal institutions have spontaneously evolved to mitigate levels of violence and potential confrontations between inmates. First, rookies (new prisoners) are subjected to initiation tests, which try to measure their rigidity (bravery) and cunning (intelligence) and assign to the appropriate subcultural group. Membership in a group of grypsmen signals the rigidity of prisoners and discourages fighting between the grypsmen or the resistance from members of lower groups. Experienced prisoners perfect eristics within the framework of prison argot, which allows them to turn real conflicts into verbal duels, use informal arbitration and learn to pretend aggression towards freshmen. All prisoners are trying to join the defensive coalitions. Inmates also perform spectacular self-injuries in accordance with secret procedures, faking desperation, but in fact minimizing damage to health and trying to get some benefits from the prosecutor or prison authorities. The collected empirical material comes from the prisons in Warsaw (Rakowiecka) and Biatoteka, where the author spent five months in 1985 as a political prisoner.
\end{abstract}

Key words: Chicken, Poland, jail, prison subculture, prison institutions, game theory, violence, Zimbardo's experiment.

\section{WPROWADZENIE}

Więzienie jest często postrzegane jako brutalna hobbesowska arena, na której osadzeni walczą, ranią się, a nawet umierają. Być może najważniejszym argumentem przemawiającym za "nieuniknioną brutalnością więzienia” jest słynny Stanford Prison Experiment (SPE). Wewnątrz zaaranżowanego więzienia role więźniów i strażników zostały losowo przydzielone studentom.

Początkowo planowany na dwa tygodnie eksperyment zakończył się już po sześciu dniach. Podobno studenci szybko zaczęli się identyfikować z przypisanymi im rolami. Niektórzy strażnicy stali się brutalni i zaczęli stosować tortury psychologiczne. Część więźniów biernie poddała się prześladowaniom, a nawet pod wpływem strażników zaczęła nękać innych więźniów (Haney i in., 1972; Zimbardo, 2011). Głównym wnioskiem wypływającym z SPE było to, że „każdy jest zdolny do okrucieństwa”, o ile przypisze mu się określoną rolę, a także pośrednia sugestia, że nie ma ucieczki przed deterministycznymi siłami „zła”2. 
Osią mojej krytyki eksperymentu Zimbardo jest obserwacja, że jego uczestnicy nie mieli motywacji, aby tworzyć instytucje ograniczające przemoc. Symulowane doświadczenie więzienne nie miało dla uczestników głębszego znaczenia, horyzont czasowy ich decyzji był krótki, nie mieli także dostępu do wytworzonych przez lata lokalnych norm i reguł postępowania wcześniejszych generacji więźniów i strażników. Krótko mówiąc, interakcje w ramach SPE nie czerpały z subkultury i jej złożonych instytucji, co zasadniczo wpłynęło na zaobserwowane zachowania. Subkultury są obecne niemal we wszystkich instytucjach, które Goffman (1961) nazwał „totalnymi”, takich jak: więzienia, areszty, obozy koncentracyjne, lecz także sierocińce, szpitale psychiatryczne, koszary wojskowe czy klasztory. Subkultury więzienne pokrywają się częściowo z wolnościowymi kodeksami zachowania, głęboko wpływają na życie więzienne i oferują złożone metody komunikacji i sygnalizacji (Gambetta, 2011; Skarbek, 2016). Siła i wyrafinowanie subkultury zależą od takich czynników, jak gęstość zaludnienia więzień oraz poziom kontroli administracyjnej (Kamiński i Gibbons, 1993; Skarbek, 2020).

W niniejszym artykule zbadane zostaną „reduktory przemocy”, czyli instytucje subkultury więziennej, które ograniczają lub eliminują przemoc, zastępując ją interakcjami o niższych kosztach transakcyjnych, albo wprowadzają w błąd obserwatorów zewnętrznych i niewtajemniczonych więźniów, pozorując brutalność niektórych zachowań. Regulacje administracyjne mają zazwyczaj ograniczony wpływ na takie instytucje. Tajna wiedza leżąca u podstaw funkcjonowania reduktorów przemocy jest przekazywana kolejnym pokoleniom więźniów poprzez nieformalną edukację, a same reduktory stanowią dobry przykład spontanicznego porządku, który wyłania się bez udziału władzy centralnej (zob. Hayek [1988], 2013; Hall i Martin, 2011; D’Amico, 2015).

Subkultura więzienna jest skrajnym przykładem trudności w badaniu nieformalnych instytucji społecznych (Kaminski, 2004b; Voigt, 2018). Więźniowie starannie ukrywają znaczenie części słów z bajery, norm, zwyczajów, a nawet prostych faktów z ich więziennego życia. Prezentowany materiał pochodzi z polskich aresztów śledczych. Został zebrany dzięki własnemu doświadczeniu - jako więzień polityczny prowadziłem badania, które z natury rzeczy są niezwykle trudne do zreplikowania. W związku z powyższym należy się Czytelnikowi kilka zdań tytułem wyjaśnienia.

Pomiędzy rokiem 1982 a upadkiem komunizmu w Polsce w 1989 roku jako student socjologii i matematyki kierowałem założonymi przeze mnie wydawnictwami podziemnymi STOP i Książnica Literacka. Wydawaliśmy bibute, czyli książki, które

2 Eksperyment Zimbardo był krytykowany za planowanie i implementację, brak losowego doboru uczestników, manipulowanie w celu osiągnięcia pożądanych rezultatów, sugerowanie standardów zachowania studentom-strażnikom podczas spotkania orientacyjnego, etc. (zob. np. Banyard, 2007; Haslam i Reicher, 2012; Haslam i in., 2018). Późniejsze badania nie potrafiły zreplikować jego wyników (Reicher i Haslam, 2006). 
peerelowska cenzura prewencyjna uznała za nielegalne. Wieczorem 11 marca 1985 roku patrol komunistycznej milicji zatrzymał nasz samochód wypełniony bibuła, a następnego dnia zostałem aresztowany. Kolejne pięć miesięcy spędziłem w aresztach śledczych na Białołęce i w Warszawie przy ul. Rakowieckiej wśród - z kilkoma wyjątkami - więźniów kryminalnych. Drugiego dnia po aresztowaniu postanowiłem poświęcić swój czas na badanie subkultury więziennej, niezwykle fascynującego tematu dla studenta socjologii zastanawiającego się nad tematem swojej pracy magisterskiej. Część materiału opisowego w tym artykule oraz kilka modeli zostało przedstawionych wcześniej, w różnych kontekstach, w moim artykule i książkach (Kamiński, 2003, 2004a, 2004b, 2006). Po upadku komunizmu subkultura więzienna w Polsce uległa transformacji, podobnie jak wszystkie inne instytucje społeczne, polityczne i gospodarcze, jej definiujące aspekty pozostały jednak niezmienione (Miszewski, 2007, 2015).

Artykuł jest zorganizowany następująco: W rozdziale drugim opisano trójpoziomowy system kastowy, zdominowany przez grypsujacych ${ }^{3}$. System ten istniał w polskich więzieniach w 1985 roku. W trzecim rozdziale przedstawiono argumentację na poparcie tezy, że choć gra w „Cykora” (ang. Chicken) lub pokrewne gry modelujące konfrontację stanowią dobry punkt wyjścia do analizy przemocy w więzieniu, to w ramach subkultury dochodzi do wykształcenia nowych gier ze zmienionymi kluczowymi parametrami przypominającymi różne mutacje „Cykora”. W rozdziale czwartym ukazano proste modele wyjaśniające, jak samosortowanie się osadzonych w grupy subkulturowe o różnym poziomie sztywności (dzielności) zmniejsza rzeczywistą przemoc. W rozdziale piątym opisano różne substytuty walki, które zmniejszają koszty transakcyjne interakcji, pozwalając obniżyć prawdopodobieństwo najgorszego wyniku. Z kolei w rozdziale szóstym omówiono koalicje obronne. W rozdziale siódmym uargumentowane zostało, że wiele przypadków pozornie dramatycznych samouszkodzeń można wyjaśnić racjonalnymi działaniami więźnia dążącego do maksymalnych korzyści, które tylko pozorują autoagresję. Ostatni rozdział stanowi podsumowanie.

\section{SUbKULTURA WIĘZIENNA I DOMINUJĄCA PODKULTURA GRYPSUJĄCYCH}

Subkultura polskich więzień ma swoje korzenie w przedrewolucyjnym Imperium Rosyjskim i kodeksach zachowań osławionego Uniwersytetu Złodziejskiego w Odessie. Te wspólne źródła sprawiły, że subkultury więzień polskich, ukraińskich i rosyjskich w czasach komunizmu były bardzo podobne (Varese, 1998; Symkovych, 2018;

3 Grypsujący to więzień należący do najważniejszej i najwyżej stojącej kasty. Termin ten pochodzi zapewne od słowa gryps, oznaczającego tajną wiadomość nielegalnie przeszmuglowaną wewnątrz lub na zewnątrz więzienia. Słowa z bajery, czyli więziennego żargonu, są zapisane kursywą. 
Kekoshvili i Slade, 2020). Początkowo kodeks więzienny ograniczał się do złodziei. Po poststalinowskiej odwilży w 1956 roku subkultura polskich więzień zdemokratyzowała się, pozwalając większości więźniów, nie tylko złodziejom, na wstąpienie do kasty grypsujacych. Po upadku komunizmu w 1989 roku normy złagodniały i najbardziej brutalne typy zachowań zanikły (Miszewski, 2007).

W 1985 roku kasta grypsujacych dominowała w większości więzień i aresztów ${ }^{4}$. W aresztach na Rakowieckiej i Białołęce jej członkowie stanowili około 70-80\% populacji więziennej. Ich kodeks opierał się na pentalogu tak zwanych zasad, które obejmowały honorowe zachowanie, solidarność z innymi grypsujqcymi, brak współpracy z administracją więzienną, utrzymywanie higieny osobistej oraz zapewnienie pewnej minimalnej pomocy wszystkim więźniom, niezależnie od ich przynależności kastowej. Zasady zostały przełożone na ponad sto praktycznych, normatywnych postulatów dotyczących konkretnych sytuacji więziennych, zwanych zachowaniami. Na przykład grypsujący nie mógł podać ręki członkowi innej kasty, strażnikowi ani większości gości. Wyjątkiem był lekarz, który uratował mu życie. Zanim podał rękę nieznanemu więźniowi, musiał zapytać: Grypsujesz? Najbardziej niebezpiecznym obiektem w celi był penis innego więźnia. Nawet przypadkowe dotknięcie penisem lub dotknięcie penisa degradowało grypsujacego do niższego statusu. Bajera, tajny żargon grypsujących, zastępowała część polskich słów więziennymi odpowiednikami i wyznaczała surowe zasady ich użycia, które wykluczały niektóre obraźliwe zwroty. Największą obelgą było porównanie grypsującego do kobiety lub nazwanie go komunistą, kapusiem lub cwelem (członkiem najniższej kasty).

Struktura władzy wśród grypsujących była na wpół demokratyczna. Przywódcy celi, maciciele, wybierani byli przez jej grypsujących lub pojawiali się naturalnie jako najbardziej agresywni i/lub energiczni grypsujący. Starszyzna oddziałów więziennych była wybierana potajemnie przez przywódców poszczególnych cel, natomiast przywódców całego więzienia wybierali potajemnie przywódcy oddziałów. Główni maciciele zazwyczaj mieli małą ekipę pomocnych grypsujacych, którzy egzekwowali ich orzeczenia i pomagali w logistyce zarządzania. Część zadań wykonywali więźniowie z niższych kast.

Usadowieni poniżej grypsujących frajerzy zajmowali środkową pozycję w hierarchii. Uważani za rzeczywistych lub potencjalnych informatorów, nie mogli jeść przy tym samym stole z grypsującymi ani podawać im ręki. Grypsujacy mógł okraść frajera, podczas gdy okradanie innych grypsujacych było surowo zakazane. W niektórych celach frajerzy stanowili większość osadzonych, ale w obu moich aresztach ich udział w populacji wynosił około 20-30\%.

4 Wszystkie osoby opisane w tym artykule to mężczyźni. Anegdotyczny materiał sugeruje, że w więzieniach dla kobiet subkultura jest łagodniejsza i że źródłem agresji są relatywnie częściej emocje niż zasady. 
Najniższa warstwa życia więziennego była zarezerwowana dla cweli. Niektórzy grypsujacy wykorzystywali ich jako dostawców usług seksualnych w roli biernej. Cwel żył wokół jaruzela ${ }^{5}$, czyli muszli klozetowej i otrzymywał kobiece imię i ubrania. Kiedy grypsujący byli znudzeni, cwele tańczyli, śpiewali i zapewniali rozrywkę. Około 1-2\% więźniów, którzy złamali którąś z najsilniejszych norm więziennych, zostawało przydzielonych do tej smutnej roli społecznej.

Status więźnia politycznego nazywanego też więźniem za Solidarność zazwyczaj stanowił niezły punkt wyjścia do przyłączenia się do grypsujących. Czasami polityczni byli zostawiani w spokoju i uważano ich za specjalną kategorię. W początkach 1985 roku było takich więźniów w całym kraju zaledwie około 150, a wielu więźniów kryminalnych nigdy nie spotkało politycznego podczas pobytu w więzieniu.

Po wejściu do więzienia każdy świeżak miał szansę stać się grypsującym, chyba że był komunistą, pedofilem, funkcjonariuszem systemu penitencjarnego lub aparatu ścigania (z wyjątkiem papug, czyli adwokatów). Zanim dołączył do grypsujących, świeżak musiał przejść serię testów inicjacyjnych (zob. obszerna analiza w Kaminski, 2003). Słabszy i młodszy świeżak mógł zostać poddany testowi przecwelania. W dniu testu współwięźniowie traktowali go źle, odpowiednio urabiając go psychologicznie. Nocą, tuż przed zaśnięciem, jeden z grypsujących mógł potajemnie zaoferować mu ochronę w zamian za przysługi seksualne. W innym teście zwanym chrztem testowano odporność na ból. Testowany więzień miał być poddany ceremonialnemu pobiciu mokrym ręcznikiem. Najlepszą strategią była jednoznaczna odmowa przy przecewelaniu i dzielne poddanie się chrzcinom. W rzeczywistości nie było żadnych konsekwencji za odmowę przysług seksualnych podczas przecwelania, a podczas chrztu nie dochodziło do żadnego pobicia. Jeśli świeżak nie okazał strachu, złe traktowanie natychmiast znikało. Oczywiście świeżak nie wiedział, że był poddawany manipulacji.

Po pomyślnym przejściu przecwelenia i/lub chrztu świeżaka mogła czekać krótsza lub dłuższa seria gierek, które testowały jego lojalność wobec współwięźniów, zdolność do szybkiego reagowania na małe wyzwania życia więziennego lub wytrzymałość. Kiedy jego spryt i męstwo zostały potwierdzone, następował ostatni etap na drodze do grypsowania - uniwersytet więzienny, czyli długi trening prawidłowego używana bajery i przestrzegania norm grypsujacych. Wykłady odbywały się w nocy na pryczach, przy zmieniającym się składzie instruktorów. Od świeżaka oczekiwano opanowania bajery, zasad i zachowań, a także umiejętności elastycznego zastosowania tej wiedzy w typowych sytuacjach więziennych. Wszystkie etapy stawania się grypsującym można było skrócić lub wydłużyć, w zależności od postępów świeżaka.

\footnotetext{
Nazwa muszli klozetowej w celi tradycyjnie pochodziła od nazwiska I sekretarza PZPR. Przed 1980 r. nazwa brzmiała gier (od Edwarda Gierka). Jaruzel zaczął zdobywać popularność po cichym zamachu stanu dokonanym przez generała Jaruzelskiego w 1980 r., który obalił Gierka. Po 1989 r. poręczniejsze słowo gier powróciło do bajery, ale jego pochodzenie zostało zapomniane (Miszewski, mail do autora).
} 
Dołączenie do kasty grypsujących zostawało symbolicznie przypieczętowane, gdy każdy grypsujący w celi podał świeżakowi rękę.

Jeśli nowy więzień nie przeszedł chrztu lub podobnego testu albo później popełnił istotne, ale nie fundamentalne wykroczenie przeciwko normom grypsujących, stawał się frajerem. Miał pewną szansę zostać ponownie grypsujacym, lecz dźwignięcie lub podniesienie, które przywróciłoby go do statusu grypsującego, wymagało bardzo mocnego dowodu sztywności, sprytu i potencjału do generowania znaczących korzyści innym grypsującym. W jednej z moich cel współwięźniowie podjęli nocną próbę wywiercenia dziury w podłodze, aby dostać się do celi poniżej, w której znajdowały się kobiety. Uczestniczący w przedsięwzięciu frajer przypadkowo zmiażdżył sobie palec. Ponieważ natychmiastowe zgłoszenie tej kontuzji zagroziłoby projektowi, czekał z tym do rana. Jego cierpienie przyniosło korzyści całej celi, a on został nagrodzony podniesieniem.

Więzień, który oblał test przecwelenia lub naruszył inną poważną normę, pozostawał cwelem do końca życia bez możliwości zmiany swojej roli. Do typowych poważnych wykroczeń należało dotknięcie przez penis innego więźnia podczas cotygodniowego prysznica, wyrażenie zgody na przysługi seksualne lub rozpoczęcie współpracy $\mathrm{z}$ administracją więzienną, śledczym lub prokuratorem.

Wszystkich więźniów obowiązywały pewne podstawowe normy życia więziennego. Więzień musiał publicznie i wyraźnie ogłaszać zamiar nakarmienia (defekacji) lub napojenia (oddawanie moczu) jaruzela, a także intencję oddania gazów. W tym celu musiał np. głośno krzyknąć: Jaruzel jest spragniony! Szamiq̨?, a jeśli nie było odpowiedzi twierdzących, mógł skorzystać z kq̨cika. Okrzyki Szamiq? były tak częste w celach grypsujacych, że frajerzy czasami nazywali grypsujacych szamakami. Normy grypsowania nie pozwalały jeść ani pić podczas karmienia jaruzela lub oddawania wiatrów.

Typowe cele więzienne były małe, od ośmiu do trzynastu metrów kwadratowych, a w każdej mieszkało od ośmiu do dziesięciu więźniów, co stwarzało motywacje do nadzorowania produkcji gazów. Przypadkowy śmierdzący kiszczak ${ }^{6}$ mógł zostać pechowcowi wybaczony, ale masowa produkcja śmierdzącego powietrza powinna zmotywować go do zajęcia się problemami swoich jelit, a może nawet krótkotrwałego postu. Prawdopodobieństwo produkcji toksycznych zapachów było potęgowane przez złej jakości żywność. Z kolei w czasie godziny policyjnej (ciszy nocnej) (około 21:00-6:00) konieczność zapowiedzi była zniesiona, zaś zabronione było jedzenie. Podczas policyjnej również masturbacja była dozwolona bez zapowiedzi.

6 Słowo kiszczak jest grą językową wykorzystującą nazwisko ówczesnego ministra spraw wewnętrznych generała Czesława Kiszczaka, któremu podlegało również więziennictwo. 
Wszyscy więźniowie musieli rozumieć podstawowe zasady bajery, aby nie urazić innych więźniów zakazanymi słowami. Grypsujący oferowali także frajerom i cwelom minimalne zapoznanie się z normami więziennymi. Na przykład żadnemu więźniowi nie wolno było kapować ani spędzać zbyt dużo czasu na rozmowach $\mathrm{z}$ administracją.

\section{MODELOWANIE BÓJEK Z WYKORZYSTANIEM GRY „CYKOR” I JEJ MODYFIKACJI}

Brutalne konfrontacje między ludźmi lub zwierzętami są często modelowane jako gra "Cykor”, zwana również „Hawk and Dove” (zob. Smith i Price, 1973). „Cykor” jest też często rozumiany jako ogólna nazwa dla wielu gier konfrontacyjnych lub nieformalnych sytuacji, które mają podobną strukturę. W takich przypadkach „konfrontacja” lub „walka” może owocować znacznymi kosztami transakcyjnymi w postaci utraty części zasobów, bolesnego zranienia lub nawet śmierci.

W typowej interpretacji gry więziennego „Cykora” dwóch więźniów może walczyć ze sobą o ograniczone zasoby więzienne albo nie podjąć walki. Z wyjątkiem wzajemnej walki, ich wypłaty są równe ilości pewnego transferowalnego zasobu. Załóżmy, że całkowita ilość zasobu wynosi 2. Jeśli jeden gracz walczy, a drugi nie, walczący otrzymuje cały zasób, a rezygnujący otrzymuje zero. Jeśli obaj nie podejmą walki, podzielą zasoby po równo. Jeśli obaj zdecydują się walczyć, wówczas skutek tej walki w postaci wysokich kosztów sprowadza obie wypłaty do -1 (patrz rys. 1).

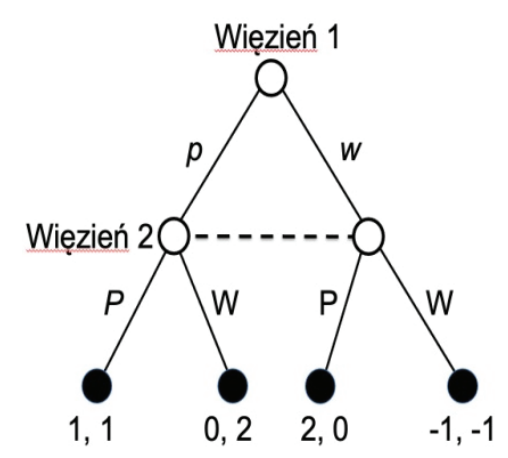

Rysunek 1. Więzienny „Cykor”

Uwaga: $p$ lub $P$ - uniknięcie walki, $w$ lub $W$ - walka.

Źródło: Kaminski 2004b. 
W więziennej interpretacji „Cykora” wybór przez obydwu więźniów strategii „walki" odpowiada konfliktowi. Pierwsza liczba w parze liczb pod czarną kropką (punktem końcowym gry) definiuje wypłatę pierwszego więźnia, a druga wypłatę drugiego więźnia. Przerywana kreska łącząca punkty decyzyjne drugiego więźnia oznacza, że gracz ten podejmuje decyzje jednocześnie z pierwszym graczem lub że nie zna wyborów pierwszego gracza.

Można szybko wskazać kilka typowych komplikacji, których tak prosty model nie uwzględnia. Prawdziwi gracze mogą mieć asymetryczne preferencje i siłę. Jeden z nich może mieć większą tolerancję na ból. Mogą być świadomi - lub nie - własnej siły lub siły drugiego gracza. Walka może też przynieść dodatkowe korzyści graczowi, wysyłając sygnał o jego wytrzymałości, który będzie cenny w przyszłych interakcjach, niezależnie od korzyści materialnych. Ponadto - chociaż zasoby można łatwo wycenić, a założenie transferowalności wypłat opartych na zasobach może być w pewnych sytuacjach uzasadnione - znacznie trudniej jest uwzględnić wypłaty takie jak honor czy reputacja. Co więcej, nasz prosty model reprezentuje jednorazową interakcję, podczas gdy sygnały sztywności są ważne tylko wtedy, gdy istnieje więcej faktycznych lub potencjalnych interakcji ${ }^{7}$.

Taka krytyka jest uzasadniona i faktycznie częściowo motywuje bardziej wyrafinowane modele przedstawione poniżej. Niemniej jednak „Cykor” jest dobrym punktem wyjścia do analizy, ponieważ reprezentuje sytuację kosztownej konfrontacji, w której gracz może ulec pokusie przyjęcia bardziej agresywnej postawy z możliwością wygrania całej stawki. Wyobraźmy sobie dwóch więźniów, przekonanych o swojej względnej sile, postawionych w sytuacji gry w „Cykora”. Gdy przyjęcie przez nich agresywnej strategii skutkuje wybuchem brutalnej walki, koszty dla obu graczy są znaczne. W efekcie obaj mogą stracić na walce więcej niż w sytuacji status quo przed walką.

Różne potencjalnie brutalne interakcje w więzieniu mogą być interpretowane jako gry wywodzące się od „Cykora”. Pomimo pozornie zbliżonej struktury na wiele pomysłowych sposobów obniżają one poważne koszty transakcyjne związane z wyborem w tej grze strategii „walki”.

\section{SortowaNiE WEDEUG OCZEKIWANEgo OPORU WOBEC PRZEMOCY}

W więzieniu byłem świadkiem tylko jednej brutalnej walki. A., więzień za Solidarność, został przeniesiony z pawilonu dla politycznych Aresztu Śledczego Mokotów do

7 Na przykład modele „Raid or Trade” uwzględniają różne koszty konfliktu i współpracy dla różnych graczy; patrz Anderson i McChesney (1994); Rider (1993) lub Skaperdas (1992). 
mojej celi. Lekceważąc moje ostrzeżenia i będąc nieświadomym, że łamie kod grypsujących, krótko po przybyciu postanowił wyczyścić wnętrze jaruzela, co było w ramach norm grypsowania zarezerwowane wyłącznie dla frajerów i cweli. Młodociany, niedoświadczony grypsujący o ksywce Małolat, którego właśnie przeniesiono do naszej celi, uznał, że więzień polityczny jest frajerem i że może bezpiecznie „pożyczyć” (czyli ukraść) jego buty. Kiedy A. zdał sobie sprawę z tego, co się stało, mocno uderzył Małolata w twarz i nastąpiła krótka, krwawa walka. Najwyraźniej obaj więźniowie nie wiedzieli, z kim mają do czynienia, i obaj byli zaskoczeni tym, co się stało. Doszło do rozbieżności w ich rozumieniu interakcji. A. bezwiednie wysłał sygnał przynależności do niższej kasty, zachowując się jak frajer lub cwel, podczas gdy Małolat, nieobeznany z więźniami politycznymi, mylnie go zinterpretował. Po krótkiej walce Małolat zaczął szanować A., a ten zadeklarował chęć poznania norm grypsujaccych.

Walki w więzieniach, tak jak wojny i inne konflikty, często wybuchają z powodu podobnych nieporozumień wynikających z niepełnych informacji o typach przeciwników lub z powodu błędnych estymacji prawdopodobieństw. Obaj przeciwnicy mogą wierzyć, że są silniejsi, a przynajmniej zdolni do stawienia oporu. W rzeczywistości jeden z nich może być znacznie słabszy i mniej odporny na ból niż drugi lub obaj mogą być sztywni. Kiedy dokładne informacje na temat sztywności więźnia zostają ujawnione poprzez serię gier i testów inicjacyjnych opisanych wcześniej, sytuacja osadzonego zmienia się diametralnie (zob. też Székely i Gambetta, 2019).

W poniższych modelach więźniowie dzielą się na dwie podstawowe kategorie: sztywni (grypsujacy) i słabi (frajerzy). Cwele są uważani za bardzo słabych. Grypsujacy są najliczniejszą subkulturową kastą, dlatego relacje wewnątrz tej kasty oraz między grypsującymi a innymi kastami są najważniejsze. Przy trzech kastach możliwych jest sześć typów interakcji, z czego trzy są stosunkowo mało istotne ze względu na małą liczebność grupy cweli, których rzadko można spotkać dwóch w jednej celi. Interakcje w obrębie kasty frajerów lub pomiędzy frajerem a cwelem są zwykle spokojne i odbywają się pod czujnym okiem grypsujacych, którzy nie chcą oglądać przypadkowych walk pomiędzy przedstawicielami niższych kast. Od frajerów i cweli oczekuje się raczej, że będą dostarczać grypsującym usług i zasobów materialnych, a poza tym nie powinni zwracać na siebie uwagi. Trzy najbardziej interesujące typy interakcji to grypsujacy-grypsujący, grypsujący-frajer oraz grypsujacy-cwel.

\subsection{Grypsujący kontra grypsujący: nieopłacalna przemoc}

Testy inicjacyjne mają na celu wyselekcjonować więźniów, którzy są sztywni, i uczynić z nich kandydatów na grypsujacych. Po nominacji na potencjalnych grypsujących więźniowie poznają tajną wiedzę grypsowania, która m.in. praktycznie 
uzasadnia dwie podstawowe zasady, formułowane jako nie wpierdalaj się $e^{8}$ i broń sie (przed wszelką agresją). Są socjalizowani do tego, aby walczyć z potencjalnym agresorem bez względu na cenę i nigdy się nie poddawać. Dowiadują się, że niewielkie korzyści z ewentualnej kapitulacji są zmarginalizowane przez późniejszy koszt utraty reputacji i wyższe prawdopodobieństwo degradacji do niższej kasty. Oprócz tego, że zostali wstępnie wyselekcjonowani jako sztywni, grypsujący uzyskują dodatkowe argumenty, że zawsze powinni zachowywać się sztywno.

Nic dziwnego zatem, że obopólne przekonanie dwóch potencjalnych grypsujacych adwersarzy, że ich przeciwnik jest gotów walczyć na śmierć i życie, minimalizuje częstotliwość prawdziwych walk. Koszty subkulturowe związane z poddaniem się w „Cykorze” podważają użyteczność tej strategii.

Typową konfrontację między dwoma grypsujacymi mogącą doprowadzić do brutalnej walki przedstawiono na rys. 2 .

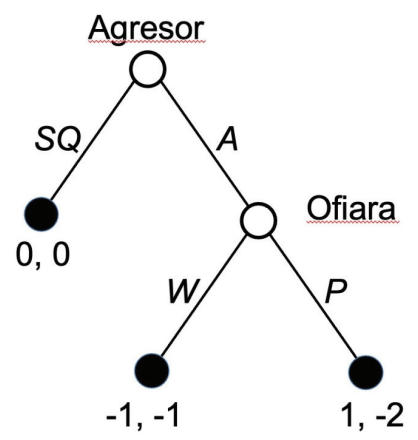

Rysunek 2. Walka grypsujących

Uwaga: $\underline{S Q}$ - status quo; $A$ - atak; $W$ - walka obronna; $P$ - poddanie się. Źródło: Kaminski (2004b, s. 126; 2006, s. 191).

Atakujący może wybrać status quo lub rzucić wyzwanie przeciwnikowi, uderzając go w twarz lub klatkę piersiową i krzycząc: Wyskakuj!, Startuj! lub Startuj na parkiet! Wyzwany więzień może walczyć lub poddać się. Zarówno osobowość, jak i socjalizacja zaatakowanego silnie stygmatyzują poddanie się. Woli zatem walczyć, a agresor ma tego świadomość. Koszty transakcyjne związane z walką czynią ją mniej korzystnym rozwiązaniem niż status quo dla obu więźniów. Determinacja obu uczestników walki sprawia, że zapewne będzie ona przypominać długi pojedynek bokserski pomiędzy dwoma silnymi i zmotywowanymi przeciwnikami. Obaj mogą

8 Przytaczam dosłowne i bardzo popularne w bajerze sformułowanie oznaczające nieingerowanie w konflikty postronnych osób. 
oczekiwać znacznego uszczerbku na zdrowiu niezależnie od tego, kto ostatecznie zostanie uznany za zwycięzcę.

Rytualne okrzyki zapowiadające potencjalną walkę zazwyczaj nie prowadzą do faktycznej walki, a sytuacja rzadko prowadzi do momentu, w którym nie ma już odwrotu. W równowadze ${ }^{9}$ groźba wzajemnych urazów w walce ze sztywnym przeciwnikiem wystarcza do powstrzymania większości konfliktów. Szkolenie i cały proces socjalizacji grypsujących gwarantuje, że przeciwnik będzie walczył do końca, nie bacząc na ból.

\subsection{Grypsujący kontra frajer: wiarygodna groźba przemocy}

Zarówno chrzest, jak i przecwelanie są okrutnymi testami niewolnymi od błędów w odkrywaniu „prawdziwego charakteru” więźnia. Również lokalne interesy grypsujących w celi mogą ograniczać skuteczność tych sprawdzianów ${ }^{10}$. Niemniej jednak wydaje się, że oba testy dość efektywnie oceniają charakter świeżaka. Grypsujący wiedzą, że frajer nie wypadł dobrze podczas chrztu, który wymagał odwagi i sztywności, lub zachował się niehonorowo, nawet po zaliczeniu chrztu. Drobne wykroczenia zazwyczaj zostają świeżakom wybaczone, a czasem nawet poważniejsza porażka może zostać zbagatelizowana, jeśli grypsujacy uznają, że była tylko „wypadkiem przy pracy". Uzyskanie statusu frajera oznacza jednak, że naruszenia były poważniejsze lub że osadzony był recydywistą w łamaniu norm grypsowania.

W grze w „eksploatację frajera” grypsujący wybiera status quo lub rzuca frajerowi wyzwanie, żądając jego własności, okradając go lub wysuwając inne, umiarkowanie upokarzające żądania. Grypsujący unikają jawnego obrażania frajerów słowami uważanymi w bajerze za obraźliwe, gdyż najgorsze traktowanie zarezerwowane jest dla cweli. Frajer może walczyć lub poddać się. Poddając się, spełnia żądania lub udaje, że nic się nie stało (rys. 3).

Odmowa frajera przejścia przez chrzest (lub inne zachowanie uważane za tchórzliwe) sygnalizuje, że boi się on walki. Podobnie jak podczas testów inicjacyjnych preferuje poddanie się. Doświadczony i proaktywny grypsujący przewiduje taką reakcję. W równowadze grypsujący rzuca wyzwanie frajerowi, który następnie się poddaje. W rezultacie grypsujacy zdobywa pewne zasoby bez walki.

\footnotetext{
9 We wszystkich grach, o ile nie zaznaczono inaczej, „równowaga” oznacza doskonałą równowagę Nasha.

10 Na przykład sam odmówiłem wzięcia udziału w chrzcie ze względu na solidarność z dwoma kolegami. Pozwolono mi go jednak zaliczyć zaocznie „ze względu na moje ogólne doświadczenie więzienne”, a w rzeczywistości ze względu na to, że nauczyłem jednego z mącicieli celi grać w brydża, a także udzieliłem cennych wskazówek medycznych szefowi wszystkich więziennych grypsujących. Zdegradowanie mnie do roli frajera sprawiłoby, że obydwaj potężni opiekunowie musieliby ograniczyć interakcje z nim obawiając się osłabienia swojej pozycji pod celq.
} 


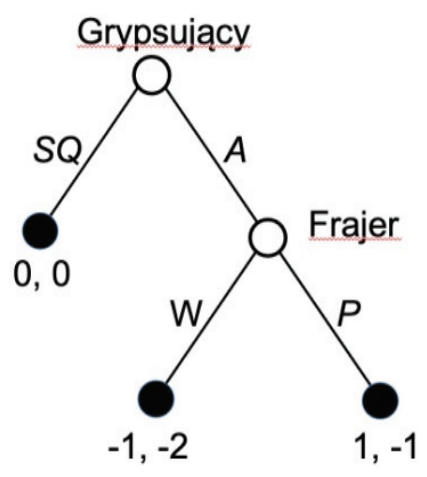

Rysunek 3. Eksploatacja frajera

Uwaga: $S Q$ - status quo; $A$ - atak; $W$ - walka; $P$ - poddanie się.

Źródło: Kaminski (2004b, s. 127; 2006, s. 193).

Najbardziej doświadczeni grypsujący są pewni swoich umiejętności „pokazywania frajerom ich miejsca”. Jeden z moich więziennych przyjaciól, Bokser, oświadczył nawet: „Wrzuć mi tylko pod celkę Gierka, Jaruzelskiego, Wałęsę i Kuronia [czołowi przywódcy komunistyczni i antykomunistyczni lat 80.]. W tydzień będą mi zamiatać parkiet i w zębach przynosić pantofle z rańca" (Kaminski, 2006, s. 195-196).

\subsection{Grypsujący kontra cwel: „Kij i marchewka”}

Cwele to więźniowie, którzy nie przeszli testu inicjacyjnego przecwelania lub zasygnalizowali słabość w większym stopniu niż frajerzy. Niepowodzenie w przecwelaniu prawie zawsze skutkuje utratą godności i obowiązkiem wyświadczania grypsującym przysług seksualnych. Subkultura uważa nawet niektóre przedmioty należące do cweli za nieczyste i zabrania grypsującym ich dotykania. Z tego powodu wielu grypsujacych powstrzymuje się od okradania cweli.

Od cwela oczekuje się więcej niż od frajera. Żądania mogą obejmować usługi seksualne, obsługę kaprysów grypsujących lub zapewnianie rozrywki powszechnie uważanej za upokarzającą, takiej jak śpiew i tańce na żądanie. Interakcje grypsujący-cwel różnią się również od interakcji grypsujący-frajer. Wymagania wobec cweli nie są formułowane jako wyraźne wyzwania. Zamiast tego cwela uczy się, że musi odgadywać zachcianki grypsującego i dobrowolnie je spełniać. W zamian otrzymuje ochronę przed przemocą (patrz rys. 4). 


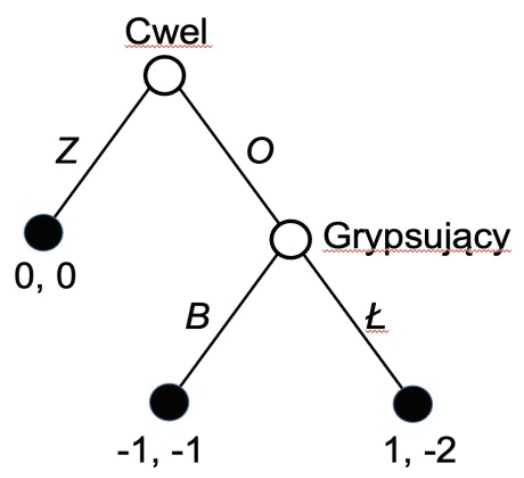

Rysunek 4. „Kij i marchewka”

Uwaga: $O$ - odmowa świadczenia usług; $Z$ - zgoda na świadczenie usług; $B$ - bicie; $七$ - łagodne potraktowanie.

Cwel może dobrowolnie współpracować i zgodzić się na świadczenie usług albo odmówić. Jeśli odmówi, grypsujący może go pobić lub potraktować łagodnie. Grypsujący, który nie zdyscyplinuje cwela, traci jednak szacunek w oczach kolegów. Posiada on zatem silną motywację do bicia. Cwel, przewidując surową karę za odmowę, zgadza się na współpracę. W równowadze cwel dobrowolnie świadczy usługi seksualne grypsującym. Co ciekawe, więzienne legendy mówią o związkach grypsujący-cwel, które przerodziły się w prawdziwe uczucie.

Podobnie jak sklepikarze „chronieni” przez mafię, cwele i frajerzy są kontrolowani za pomocą wiarygodnych gróźb przemocy. Korzyści czerpane przez grypsujących są zwykle współmierne do oczekiwanego oporu, który jest estymowany w oparciu o przynależność kastową ofiary. Grypsujący uczą się, kiedy przestać, zanim zajdą za daleko. Frajer jest uważany za źródło drobnych zysków, zaś może być poniżany tylko wtedy, gdy wymaga tego obrona honoru grypsujacego. Z kolei wykorzystywanie i upokarzanie cweli uważane jest za bezpieczne. Przemoc jest jednak uznawana tylko za środek do celu, a frywolne lub sadystyczne poniżanie i bicie jest niechętnie widziane.

\section{SUBSTYTUTY PRZEMOCY}

Ponieważ walka jako metoda rozwiązywania sporów jest kosztowna i niebezpieczna, pojawiały się różne jej substytuty. Zamiast walczyć, grypsujący urządzali pojedynki językowe, pozorowali bijatykę, a także zlecali rozwiązywanie konfliktów niezależnym arbitrom. 


\subsection{Pojedynki językowe}

Więzienna bajera, slang więźniów wywodzący się z szerszego języka „nie tylko opisuje istniejącą rzeczywistość instytucjonalną, ale jest częściowo konstytutywna dla tej rzeczywistości" (Searle, 2005). Bajera zmienia postrzeganie świata, nazywając powszechne w więzieniu sytuacje, emocje, przedmioty, a pomijając te, które są szkodliwe, nieefektywne lub pojawiają się z małym prawdopodobieństwem. Co ważniejsze, bajera kształtuje przekonania i oczekiwania wypłat w sytuacjach specyficznych dla więzienia. Więzień, który mistrzowsko opanuje bajerę w stopniu wykraczającym poza powszechne słownictwo, wysyła potężny i niemożliwy do podrobienia przez świeżaka sygnał, że doskonale rozumie więzienną rzeczywistość i potrafi umiejętnie reagować na zagrożenia. Nic dziwnego, że agresja słowna w „instytucjach totalnych”, takich jak więzienia czy gangi, często zastępuje przemoc fizyczną (Hamill, 2010, s. 111).

Pojedynki językowe, często połączone ze straszliwymi gestami i grymasami, wybuchały, gdy podczas gry w domino, karty lub szachy grypsujący uznawali, że ktoś oszukuje. Te banalne sprzeczki były często wstępem do ostrych konfliktów. Zarówno oskarżyciele, jak i oskarżeni udawali, że są na granicy wytrzymałości i gotowi do walki. Obrzucali się (jak się mogło wydawać) najgorszymi obelgami, ale starannie przy tym pilnowali się, aby naprawdę nie obrazić przeciwnika poprzez złamanie norm bajery. Reguły w bajerze dopuszczały wiele pozornie obraźliwych przekleństw, ale zakazywały innych, które uważano za faktycznie obraźliwe. Grypsujący obrażony niedopuszczalnym bluzgiem był zobowiązany walczyć w obronie swojego honoru, bo w przeciwnym razie ryzykował degradację.

Szczególnie barwny pojedynek na bajerę zarejestrowałem na żywo w celi szpitalnej między 15 kwietnia a 9 maja 1985 roku (Kaminski, 2006, s. 145). „Bokser” grał w warcaby z "Czachą” i oskarżył go o ukrycie jednego pionka. Słowa dodane w nawiasach \{\} wskazują na możliwe modyfikacje, które ze względu na tajne zasady bajery sprawiłyby, że przekleństwo byłoby głęboko obraźliwe dla przeciwnika. Wrażliwszy czytelnik może pominąć wymianę i przejść bezpośrednio do analizy semantyki pojedynku.

\section{„Bokser” kontra „Czacha”}

Bokser: Żeby ci gówno w poprzek stanęło!

Czacha: Jak ci pierdolnę, to się zesrasz tym, co rok temu jadłeś!

Bokser: Żeby ci chuj na wolności \{w więzieniu\} stawać nie chciał!

Czacha: Żeby ci jedno jajko uschło \{obydwa jajka uschły\}!

Bokser: Zaszyj się mendami w rudą pizdę \{dupę\}! 
Czacha: Chuj ci w pizdę \{dupę\}!

Bokser: Chuj twojej ciotce \{tobie\} w dupę!

Czacha: Jak cię słyszę, to mi chuj do tyłu \{normalnie\} staje!

Bokser: Chuj ci w serce \{dupę\}!

Czacha: Chuj ci w dupę do połowy \{do końca\}!

W tym momencie obaj bajermistrze wybuchnęli śmiechem i przyjaźnie zaczęli analizować ostatni bluzg. Dylemat polegał na tym, czy kwalifikator „połowa” wystarczył, aby oczyścić skądinąd obraźliwe wyrażenie z niedozwolonego znaczenia. Dyskusja przerodziła się następnie w rozważanie o maksymalnym dopuszczalnym procencie „chuja”, który mógłby wejść w „dupę” przeciwnika, zanim ten zostanie obrażony. Obaj grypsujący zgodzili się, że z dala od stosunkowo zrelaksowanego szpitalnego środowiska lepiej nie używać takiego zwrotu, który znalazł się zbyt blisko granicy oddzielającej dozwolone od zakazanych bluzgów. „Czacha” rytualnie wycofał swoje ostatnie przekleństwo, używając standardowego zwrotu Skiciorem! (To był żart!). Pozostali mieszkańcy celi byli wyraźnie pod wrażeniem szybkości, z jaką generowane były przekleństwa, a także ich pomysłowości.

Nawet drobna modyfikacja obelgi w pojedynku może zmienić ją w zakazaną. Na przykład przeklinanie ciotki grypsujacego było dozwolone, ponieważ nie było ono wymierzone bezpośrednio w jego osobę. Innym sposobem na wygenerowanie bezpiecznego wyzwiska było obrażanie tych narządów anatomicznych, których grypsujący ewidentnie nie posiadali lub które były uznawane za nieobraźliwe, a sugerowana w bluzgu czynność musiała być niemożliwa do przeprowadzenia (np. serce).

Podczas mojego pięciomiesięcznego pobytu w areszcie zaobserwowałem kilkanaście pojedynków słownych o różnym poziomie wyrafinowania, ale żaden z nich nie przerodził się w brutalną walkę. Agresja została przekształcona w potyczki werbalne o niskich kosztach transakcyjnych, które również dały przeciwnikom czas na ochłonięcie. Pojedynki językowe zmodyfikowały zatem wypłaty w "Cykorze”, dramatycznie obniżając stawki. Co więcej, znajomość bajery, udoskonalana przez wielu grypsujacych, sygnalizowała innym grypsujacym kompetencje subkulturowe. W podobnym duchu grypsujący używali werbalnych substytutów fizycznej agresji podczas interakcji ze strażnikami.

\subsection{Pozorowana walka}

Agresywne zachowanie można upozorować. Oszustwo było podstawą większości gierek grypsujących. Gierki były zainscenizowanymi testami sytuacyjnymi świeżaków 
w środkowym okresie inicjacji, który następował po pomyślnie zdanych testach przecwelania i/lub chrztu, i często opierały się na skomplikowanym scenariuszu zaaranżowanym przez współpracujących ze sobą grypsujacych. W typowej gierce świeżak mógł zostać wyzwany przez najsilniejszego grypsujacego w celi na walkę bokserską (Niewolski, 2003). Jeśli świeżak odmówił walki, oblewał test i mógł zostać poddany surowszemu traktowaniu i dłuższym testom. Jeśli podjął wyzwanie i gotów był walczyć, nic się nie wydarzało. Do walki w ogóle nie dochodziło! Celem tego testu było zmuszenie świeżaka do zasygnalizowania swojej słabości - odmowy udziału w walce - lub sztywności - przyjęcia wyzwania ${ }^{11}$. Podobnie grypsujący mógł z groźną miną poprosić świeżaka o „pożyczenie” mu swetra, spodni lub butów (Kaminski, 2003). Było oczywiste, że własność świeżaka nie zostanie zwrócona. Odmowa „pożyczki” nie skutkowałaby jednak żadnymi sankcjami. We wszystkich tych przypadkach nie dochodziło do walki lub sankcji za odmowę „pożyczki”, ponieważ sytuacja była inscenizowana jedynie w celu sprawdzenia sztywności lub lojalności świeżaka.

Wiele gierek było również inscenizowanych dla frajerów. We wszystkich takich sytuacjach grypsujacy wykonywał agresywny ruch lub żądał niebezpiecznego działania, podnosił głos i sugerował, że odmowa spełnienia jego żądania spowoduje brutalną walkę lub inne nieprzyjemne konsekwencje.

W grze „Pseudokonfrontacja” (rys. 5) grypsujący wyzywa świeżaka na pojedynek $\left(\right.$ Kaminski, 2003) ${ }^{12}$.

Agresor może wybrać status quo (ze znormalizowanymi wypłatami równymi zero dla obu graczy) lub rzucić wyzwanie świeżakowi. Nie zna stopnia sztywności świeża$k a$. Świeżak może być słaby z prawdopodobieństwem $p$ lub sztywny z prawdopodobieństwem 1-p. Agresor wchodzi do gry z pewnym szacunkiem prawdopodobieństwa, opartym na wcześniejszym zachowaniu świeżaka. Świeżak może walczyć lub poddać się. Słaby świeżak ma motywację do poddania się, podczas gdy sztywny świeżak woli walczyć i bronić swojego honoru lub własności. W równowadze tej gry istnieje pewne graniczne prawdopodobieństwo $p^{*}$ (przy założonych wypłatach równe 0,5 ), że agresor rzuca wyzwanie świeżakowi, gdy $p>p^{*}$; wybiera $S Q$, gdy $p<p^{*}$, i jest indyferentny wobec obu strategii dla $p=p^{*}$. Po wyzwaniu słaby świeżak poddaje się, a sztywny świeżak walczy. Typ świeżaka jest następnie ujawniany przez podjęte działanie.

11 Rekruci do IRA (Irlandzkiej Armii Republikańskiej) lub innych organizacji rewolucyjnych mogą zostać poproszeni przez rekrutującego o zabicie zdrajcy w organizacji (Pontecorvo, 1966; Loach, 2002). Jeśli rekrutowany odmówi, nie zostanie przyjęty do organizacji. Jeśli się zgodzi i zacznie wykonywać plan „zabicia zdrajcy", zostaje zatrzymany w ostatniej chwili przez rekrutującego. W rzeczywistości nie ma żadnego zdrajcy, a nowicjusz zostaje postawiony w zaaranżowanej sytuacji, która zmusza go do zasygnalizowania słabości lub sztywności.

12 Ten i niektóre inne modele analizowane w tym artykule obejmują pary gier. Alternatywnym sposobem modelowania byłoby wykorzystanie gier z niekompletną informacją. Uważam, że korzystanie z par gier jest jednak prostsze i bardziej intuicyjne. 


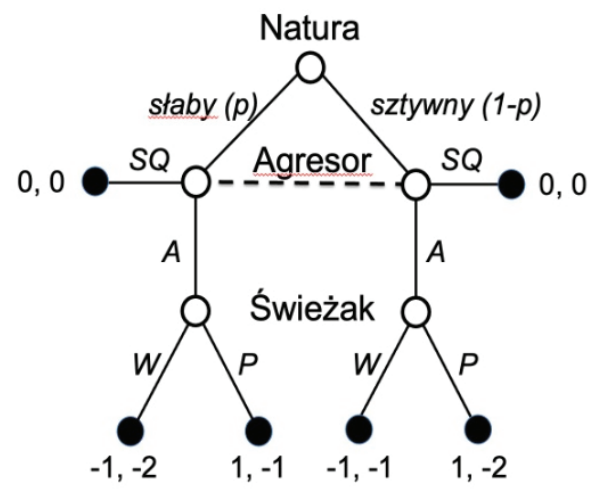

\footnotetext{
Rysunek 5. Fikcyjna „Pseudokonfrontacja”: zainscenizowana gra według niepoinformowanego Świeżaka

Uwaga: $A$ - atak, $S Q$ - status quo, $\mathrm{W}$ - walka w obronie własności i honoru, $P$ - poddanie się. Prywatna wiedza świeżaka: jest sztywny lub słaby. Świeżak wierzy, że gra zakończy się, kiedy odpowie na wyzwanie. Słaby świeżak woli się poddać, sztywny świeżak woli walczyć.

Źródło: Kaminski 2006, s. 80.
}

Opisana powyżej gra pokazuje, jak niepoinformowany świeżak zazwyczaj postrzega sytuację. Agresor i jego wspólnicy - pozostali współwięźniowie - bardzo skutecznie odgrywają swoje role, aby podtrzymać iluzję zagrożenia. Komentują przeszłe walki, złamane kości i wspominają pobitych świeżaków, którzy odmówili przyjęcia wyzwania. Gdyby agresor musiał rzeczywiście walczyć ze sztywnym świeżakiem, byłby w gorszej sytuacji, niż gdyby wybrał status quo. Jednak w rzeczywistości agresor nigdy nie walczy, ponieważ prawdziwa gra jest nieco bardziej skomplikowana (patrz rys. 6).

W tej grze, jeśli świeżak zdecyduje się walczyć, agresor ma do wykonania kolejny ruch, którego świeżak jest nieświadomy. Agresor może kontynuować walkę lub ogłosić, że świeżak ,jest dobrym chłopakiem”, pochwalić jego odwagę i wycofać się z walki. Ta ukryta opcja jest istotą gierki: kiedy świeżak niechętnie przygotowuje się do walki i wydaje agresywne okrzyki, agresor, bacznie go obserwując, ogłasza: „Dobra, dobra, widzę, że jesteś sztywnym chtopaczyna, nie jaraj się. To były tylko zbytki". Ważne jest tylko doprowadzenie świeżaka do sytuacji, z której pozornie nie może się już wycofać i uniknąć walki. Agresor jest natychmiast wspierany przez innych współwięźniów, którzy potwierdzają: „Tak, to był test, świeżak, zrelaksuj się”, aby powstrzymać zirytowanego świeżaka przed eskalacją konfliktu.

W równowadze doskonałej w tej grze agresor zawsze rzuca wyzwanie, niezależnie od prawdopodobieństwa, czy świeżak jest słaby; świeżak zawsze walczy, a agresor zawsze oznajmia. Ale kiedy strategia równowagi świeżaka w fikcyjnej „Pseudo- 
konfrontacji" (rys. 5) jest połączona ze strategią równowagi agresora z prawdziwej „Pseudokonfrontacji” (rys. 6), scenariusz wydarzeń jest następujący: agresor rzuca wyzwanie; sztywny świeżak demonstruje, że jest gotów do walki, podczas gdy słaby świeżak poddaje się; agresor ogłasza, że sztywny świeżak zdał test. Słaby świeżak poddaje się i nie wie, że mógł podjąć walkę bez żadnych negatywnych konsekwencji. Świeżacy, którzy zdają sobie sprawę, że bycie sztywnym jest zawsze optymalne - być może po jednej, a być może po kilku podobnych grach - robią pierwszy mentalny krok w kierunku zostania grypsujacymi.

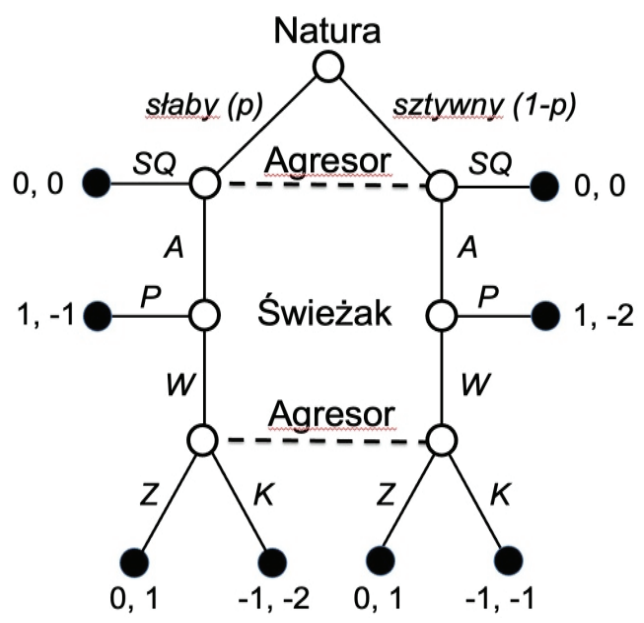

\section{Rysunek 6. Prawdziwa „Pseudokonfrontacja”: gra postrzegana przez poinformowanego} grypsujacego

Uwaga: $S Q$ - status quo, $A$ - atak, $W$ - walka obronna, $P$ - poddanie się, $K$ - kontynuacja walki, $Z$ - zakończenie interakcji i oznajmienie, że świeżak przeszedł test pomyślnie. Prywatna wiedza świeżaka: jego typ, słaby lub sztywny.

Źródło: Kaminski 2006, s. 82.

Warto zauważyć, że chociaż interakcja między agresorem a świeżakiem jest potencjalnie brutalna, nigdy nie kończy się walką niezależnie od typu świeżaka. Cenne zasoby więzienne, takie jak swetry, spodnie, buty, koszule lub zegarki, zmieniają właściciela przy minimalnych kosztach transakcyjnych.

\subsection{Afery i arbitraż}

W wielu więzieniach nieformalne samorządy więzienne wspomagają rozwiązywanie konfliktów (Skarbek, 2014). Zazwyczaj arbitrami są przywódcy grypsujących - starszyzna i maciciele. Arbiter może otrzymać za rozstrzyganie sporów wynagrodzenie w postaci części spornych zasobów. Zlecenie rozdziału zasobów zewnętrznemu 
rozjemcy wiąże się z niższymi kosztami transakcyjnymi, jest więc alternatywą dla "Cykora” z walką jako potencjalnym efektem. Według moich obserwacji zdecydowana większość konfliktów handlowych rozstrzygana była przez arbitrów.

Geneza typowej afery lub zadymy - interakcji lub wymiany, która doprowadziła do konfliktu - może wydawać się banalna dla obserwatora zewnętrznego. Transakcja wymienna na więziennym czarnym rynku nie powiodła się. Ponieważ więźniowie w więzieniu spędzają większość czasu w celach, w wielu takich transakcjach biorą udział pośrednicy, tacy jak fryzjerzy, bibliotekarze lub kucharze. Wszyscy korytarzowi, czyli więźniowie poruszający się po korytarzach oddziałów i dostarczający więźniom usługi, książki lub posiłki, mogą jednocześnie przenosić towary i pieniądze z jednej celi do drugiej. Niektóre zasoby lub pieniądze mogą zniknąć podczas takiego transportu. Ze względu na zaangażowanie pośredników wiedza o wymienianych zasobach może być niepełna, a niespójne relacje zaangażowanych stron mogą prowadzić do konfliktu. O ile konflikty przy grze w domino lub warcaby wybuchają nagle i kończą się szybko, o tyle do rozstrzygnięcia sporów handlowych zazwyczaj potrzeba więcej czasu. Rozstrzyganie takich sporów wymaga zebrania precyzyjnych informacji o pośrednikach oraz o drodze, którą przebyły dobra zmieniające właściciela.

Według byłego więźnia, życie arbitra jest pełne ciężkiej pracy:

$\mathrm{Z}$ wodzem szamaków jest cały czas pod celą napięcie, bo wódz prowadzi niekończące się nawijki przez lipo, rozstrzyga spory wśród szamaków, komuś grozi, ubliża, przebacza. W takiej celi częste są kipisze, wizyty wychowawcy, raporty, co z kolei jest utrapieniem dla pozostałych więźniów, stanowiących przypadkowe tło wodza. Bez przerwy ktoś podaje gryps, puka w ścianę, woła ze spacerniaka. Wódz często ma też adiutantów, z reguły małolatów z długim stażem poprawczaków, domów dziecka i Iławy.

Przezgredzone małolatki przyjeżdżają z Iławy do Barczewa i kontynuują swoje spory.

Adiutanci przejmują za wodza grypsy w lipie i w jego imieniu odpowiadają, oni też dostają często raporty i idą na kabarynę. Ale na nich też spływa trochę splendoru i chwały, są obecni przy dzianiu się wielkich spraw, tworzą historię (Niesiołowski, 1989, s. 98-99).

\section{KoAlicJE}

Innym rodzajem reduktora przemocy, który opiszę tylko pokrótce, jest waflarnia, czyli koalicja więźniów, która jest mniej formalna i ma bardziej płynną strukturę niż 
kasty. W małych celach, w których znajduje się 8-9 więźniów, często tworzą się dwie konkurujące ze sobą koalicje. Jedna z nich może być „minimalnie wygrywająca” ze względu siłę jej członków, czyli może zawierać minimalną liczbę więźniów niezbędną do rządzenia celą. Taka koalicja ma wystarczającą moc, aby kontrolować najważniejsze rzadkie zasoby celi, takie jak lepsza pościel lub piżamy, łóżka piętrowe albo dodatkowy dżem lub masło pozyskane od korytarzowych. Członkostwo w rządzącej koalicji jest często tymczasowe. Aktywny i bezwzględny przywódca koalicji może włączyć lub wykluczyć mniej znanych członków koalicji w zależności od ich wstępnej przydatności. Może dołączyć więźnia, który właśnie otrzymał rakietę z domu (czyli dużą paczkę żywnościową), a wykluczyć innego, którego rakieta właśnie została skonsumowana w ramach koalicji (Kaminski, 2004b, s. 114-115). Oprócz dominującej waflarni inna koalicja może obejmować niektórych lub wszystkich innych grypsujących, którzy chcą zawrzeć pakt obronny. Frajerzy i cwele nie mogą dołączać do waflarni z grypsujacymi.

W stodołach, dużych celach z 40-50 więźniami, struktury koalicyjne są bardziej złożone, a koalicje są zazwyczaj mniejsze. Ich podstawową funkcją jest generalnie obrona. Można również tworzyć tymczasowe koalicje (herbaciarnie) w celu wspólnego picia czajury.

Jedną z motywacji do tworzenia koalicji obronnych jest zapobieganie sytuacjom, w których doświadczony więzień może przekonać świeżaka do rzucenia wyzwania słabemu więźniowi i pobicia go w celu uzyskania reputacji sztywnego (zob. np. Kaye, 1998; Wojciechowski, 1981). Taka bójka może pomóc świeżakowi w uzyskaniu reputacji sztywnego. Jednak w więzieniu o wyrafinowanych strukturach koalicyjnych więźniowie są chronieni przed takimi prymitywnymi atakami. Członek koalicji nie jest atrakcyjnym kandydatem na ofiarę, ponieważ jego wafle będą go bronić. W takim przypadku waflarnia agresora, o ile jest on jej członkiem, może być zmuszona do zaangażowania się w poważny konflikt międzykoalicyjny. Grypsujący starają się zapobiegać zadymom na tak dużą skalę, chyba że powód jest poważny.

\section{StRategiczna MaNipUlacja ZDROWIEM}

Duża część poważnych okaleczeń i kontuzji w więzieniu powstaje w wyniku samouszkodzeń, które - tak jak symulowanie choroby oraz odmowa jedzenia (np. strajk głodowy) lub poddania się leczeniu - służą więźniom do strategicznego wykorzystywania własnego zdrowia. Narzędzia te mogą być elementami złożonego planu uzyskania różnych korzyści od władz więziennych, systemu sądowniczego, prokuratora, policji lub lekarzy, którzy podejmują ważne dla osadzonego decyzje (Kamiński, 
2004b, rozdz. 8). Dla obserwatora zewnętrznego, który nie jest świadomy prawdziwych intencji i celów więźnia, samouszkodzenie może sprawiać wrażenie desperackiej i emocjonalnej reakcji na dolegliwości uwięzienia.

Popularne rodzaje samouszkodzeń w polskich więzieniach w 1985 roku obejmowały: wyhuśtanie (fałszywe powieszenie), pochlastanie (pocięcie przedramienia, ale także nogi i brzucha), połyk (najczęściej przedmiotów metalowych), oparzenie (zazwyczaj nogi wrzątkiem), podpalanie (zazwyczaj nogi, często pastą do podłogi), wstrzyk (różnych substancji do mięśni w celu wywołania infekcji), wbitkę (wbicie igły lub gwoździa w czoło lub źrenicę oka) (pełniejsza lista jest zamieszczona w: Kamiński, 2004b).

Samookaleczenia mogą być opłacalne ze względu na powszechną, uniwersalną, humanitarną normę "traktowania chorych z większą troską”, która jest egzekwowana przez międzynarodowe agencje nadzorujące, takie jak Amnesty International, oraz wewnętrzne procedury więzienne. Co więcej, władze więzienne starają się o jak najlepsze statystyki efektywności w swojej jednostce, utrzymując niski poziom obrażeń ciała, chorób, zgonów i ogólnego nieładu, a także minimalizując koszty usług medycznych. Osadzeni z kolei korzystają z możliwości stwarzanych im przez lokalne regulacje, aby wywierać presję na decydentów więziennych. Do najważniejszych celów należą skrócenie warunkowe kary, zawieszenie wykonania kary, przeniesienie do wygodniejszego szpitala więziennego, ucieczka z wrogiej celi, a nawet koordynacja spotkania ze wspólnikiem w celi szpitalnej (zob. Kamiński, 2004b, rozdz. 8).

Spektakularnym przykładem strategicznego działania z elementami symulacji i samouszkodzenia jest wyhuśtanie, czyli powieszenie się. W nocy więzień wiesza się na kratach celi, ale tuż przed śmiercią ratują go współwięźniowie. Nieprzytomny nieszczęśnik zostaje przewieziony do szpitala więziennego, być może o włos unikając śmierci. Czy tak straceńcze działanie może być czymś innym niż desperackim krzykiem o pomoc ze strony wyczerpanego emocjonalnie więźnia?

Oficjalne raporty z Polski z końca lat 80 . XX wieku sugerują, że więźniowie dokonywali około 1500 samouszkodzeń rocznie (nieoficjalne szacunki mówią o 4000 do 6000), w tym około 132 wyhuśtań, z których 15-30 kończyło się śmiercią. Około 10-20\% prób samobójczych wyhuśtań kończyło się więc śmiercią. W ogólnej populacji odsetek ten szacuje się na 60-85\% (Tintinalli, 2010; Spicer i Miller, 2000). To znacząca rozbieżność. Być może współwięźniowie mogą częściej zauważyć próbę samobójczą i szybciej interweniować. Istnieje jednak inne możliwe wytłumaczenie: duża część, a być może większość prób samobójczego wyhuśtania jest inscenizowana.

W subkulturze grypsujących fałszywe wyhuśtanie jest jednym z wielu rodzajów kontrolowanego samouszkodzenia. Naucza się o nim podczas wcześniej opisanego uniwersytetu więziennego, czyli na etapie, kiedy to kandydat na grypsującego 
pomyślnie zdał już wszystkie wymagane testy inicjacyjne, które mogły obejmować przecwelania, chrzest i/lub gierki. Nie jest to jednak wiedza powszechna. Tylko elita grypsujących, eksperci więziennej subkultury i nieformalni szefowie więzienia znają te procedury. Swoją sekretną wiedzą dzielą się tylko z wybranymi świeżakami, ponieważ nawet perfekcyjnie wykonane wyhuśtanie może spowodować poważne obrażenia. Aby warto było podjąć ryzyko, musi ono generować znaczące korzyści dla więźnia, takie jak zawieszenie wyroku lub zwolnienie warunkowe.

Wyhuśtanie często odbywa się w areszcie, wkrótce po osadzeniu, po okresie starannych przygotowań. Większość więźniów wychodzi z celi na codzienny, upragniony, półgodzinny spacer, ale potencjalny samobójca i jego partner rezygnują ze spaceru i doskonalą swoje procedury w tymczasowo pustej celi. Wyhuśtania mają miejsce późno w nocy, po tym jak partnerzy uznają, że są wystarczająco przygotowani. Samobójca już wcześniej przetrenował, jak szybko zrobić sznur i pętlę z prześcieradła, przywiązać ją do krat okiennych na odpowiedniej wysokości i delikatnie wykopać spod nóg wiadro lub taboret. Nie chciałby bowiem przypadkiem skręcić karku! Śmierć przez powieszenie następuje albo przez uduszenie, albo przez przerwanie rdzenia kręgowego (skręcenie karku). Tego ostatniego można uniknąć poprzez staranne kontrolowanie upadku.

Podczas samej próby wyhuśtania partner udaje, że śpi, ale w rzeczywistości pilnie monitoruje sytuację. Kiedy wiadro przewraca się, a samobójca „zaczyna tańczyć na linie”, partner jest przygotowany do działania. Każda zmiana wzorca „tańca” może sygnalizować utratę przytomności. Kiedy partner uznaje, że do tego doszło, natychmiast rozpoczyna dobrze przećwiczoną sekwencję ruchów, chwytając samobójcę za nogi i odcinając mu linę (używając zdobytego na tę okazję nielegalnego noża lub żyletki), jednocześnie podnosząc alarm. Inni więźniowie powoli się budzą i dołączają do narastającej wrzawy. Wkrótce wszyscy więźniowie krzyczą i uderzają aluminiowymi kubkami w stalowe drzwi, aby zaalarmować strażników. Podczas gdy strażnicy biegną po korytarzu i dzwonią po lekarza, nieprzytomny samobójca leży na podłodze, nieświadomy wywołanego przez siebie pandemonium.

U podstaw skuteczności wyhuśtania leży błyskotliwa obserwacja, że potencjalny samobójca stoi przed dwoma krytycznymi progami czasowymi, a nie tylko jednym. Najpierw po zazwyczaj kilkunastu sekundach uciśnięta tętnica szyjna wstrzymuje dopływ krwi do mózgu i traci się przytomność, ale wciąż jeszcze żyje. Po następnych kilku lub kilkunastu minutach dochodzi do śmierci. Okno czasowe oddzielające utratę przytomności od śmierci jest zatem dość szerokie. Zadaniem partnera samobójcy jest wcelowanie we wczesny okres tego „okna nieprzytomności”, aby uruchomić akcję ratunkową. Samobójca ma być nieprzytomny, ale ma też pozostać przy życiu! Partner musi działać szybko, ale nie przedwcześnie. 
Utraty przytomności nie można symulować, ponieważ każdy lekarz łatwo zidentyfikuje zwyczajne aktorstwo. Oczywiście czasem trafiają się wyhuśtania zakończone śmiercią w wyniku nieudolnych błędów, a także prawdziwe, napędzane emocjami samobójstwa, jednak z wielu relacji wynika, że sytuacje symulowanego samobójstwa są częstsze.

Celem pozorowanego samobójstwa jest wywołanie w umysłach obserwatorów fałszywego obrazu zdarzenia. Na rys. 7 przedstawiono prosty model wyhuśtania widziany z perspektywy niewtajemniczonego obserwatora. Więzień może nic nie robić lub próbować popełnić samobójstwo. Nie ma w tym modelu partnera podejrzewanego o współpracę przy wyhuśtaniu; samobójstwo wygląda na autentyczne. Jeśli samobójca podejmuje próbę, następuje ruch Natury. Z pewnym prawdopodobieństwem $p$ zostaje on uratowany, gdy jego koledzy z celi budzą się i odcinają go na czas. W bardziej możliwym scenariuszu śmierć następuje z prawdopodobieństwem 1-p. Jego autentyczną desperację i pragnienie śmierci potwierdza powszechne przekonanie, że prawdopodobieństwo ratunku w przypadku poważnych prób jest stosunkowo małe. Wiarygodność wysiłku potwierdza utrata świadomości, której nie można symulować. Niewtajemniczony obserwator uważa więc, że więzień w wiarygodny sposób sygnalizuje swoje życzenie śmierci (patrz rys. 7).

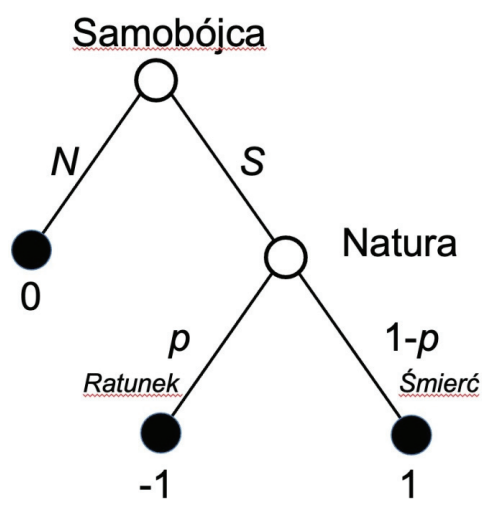

Rysunek 7. Fałszywe wyhuśtanie widziane z perspektywy niewtajemniczonego obserwatora Uwaga: Prokurator lub inny decydent zakłada, że doszło do wiarygodnej próby samobójczej i że samobójca preferuje śmierć od ratunku $(1>-1)$. Samobójca może pozostać bierny $(N)$ lub wyhuśtać się $(S)$.

Rzeczywista gra w fałszywe wyhuśtanie jest inna. Oprócz samobójcy w grze bierze udział tajny wspólnik, który udaje osobę postronną. Ruch Natury ogranicza się jedynie do błędu wspólnika. Błędy takie oczywiście zdarzają się, ale ich prawdopodobieństwo jest niskie, ponieważ procedura jest dobrze przećwiczona, a motywacja 
partnera do przeprowadzenia udanej akcji ratowniczej silna. Jeśli mu się nie uda i samobójca zginie, starszyzna grypsujących zbada sprawę. Wtajemniczona w procedurę wyhuśtania starszyzna dobrze rozumie, co się stało i nietrudno jest jej ustalić, kto był za to odpowiedzialny. Partnera można łatwo zidentyfikować jako więźnia, który wielokrotnie przebywał z samobójca w celi podczas więziennych spacerów. Jeśli okaże się, że partner dopuścił się zaniedbania, zostanie surowo ukarany - być może nawet degradacją do roli frajera - lub przynajmniej poddany ostracyzmowi. Z drugiej strony, odnoszący sukces partner zyskuje wdzięcznego współwięźnia oraz szacunek innych doświadczonych grypsujących.

Poniższa gra przedstawia strukturę rzeczywistej gry fałszywego wyhuśtania.

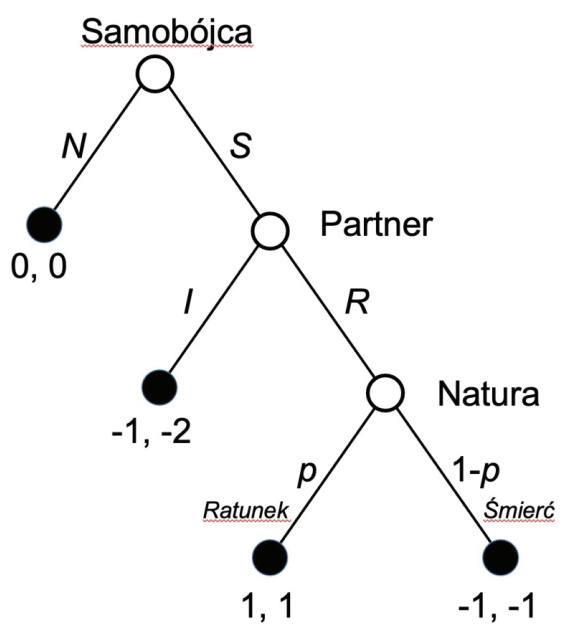

Rysunek 8. Fałszywe wyhuśtanie: rzeczywista gra

Uwaga: Samobójca może nie podejmować próby samobójczej $(N)$ lub próbować powiesić się $(S)$. Partner może włożyć niewiele wysiłku w jego uratowanie $(I)$ - co prowadzi do śmierci samobójcy - lub włożyć maksymalny wysiłek w jego uratowanie $(R)$, co ogranicza prawdopodobieństwo śmierci do niewielkiego 1-p. Obaj gracze wolą udany ratunek od śmierci samobójcy. Wypłata partnera za niewielki wysiłek lub niedbalstwo przy ratowaniu jest najniższa. Prawdopodobieństwo ratunku $p \approx 1$ (prawie jeden); 1- $p$ to małe prawdopodobieństwo błędu. Wypłata -1 w przypadku śmierci oznacza jedynie najmniej preferowany przez Samobójcę wynik w grze i nie jest porównywalna z wypłatami z innych gier.

Udane fałszywe wyhuśtanie może przynieść więźniowi cenne korzyści, nie jest jednak pozbawione ryzyka. Więzień Tomek, który jako pierwszy opisał mi fałszywe wyhuśtanie, cierpiał na częściowe niedotlenienie mózgu i przejściowy paraliż prawej ręki. Jego partner odciął go nieco za późno. Tomek został aresztowany na gorącym uczynku i natychmiast oskarżony. Jako recydywista oczekiwał długiego wyroku. Prokurator uznał jednak, że jego próba samobójcza była realna i że następ- 
na próba może się powieść. Zatem zarzuty zostały zastąpione mniej poważnymi. Tomek został zwolniony z więzienia i obiecano mu wyrok w zawieszeniu. Symulując „wiarygodny” sygnał desperacji, osadzony okazał się być zdolny i zmotywowany w oczach prokuratora do popełnienia samobójstwa, przez co dostarczył motywacji prokuratorowi do wyboru paragrafu pozwalającego uniknąć tego wzajemnie niepożądanego scenariusza.

Wyhuśtanie jest jednym z wielu rodzajów samouszkodzeń dokonywanych przez więźniów wymuszających korzyści na ich otoczeniu instytucjonalnym. Zwykle inscenizacja jest przekonywająca, kiedy potencjalny decydent $w$ instytucji jest nieświadom tego, co się naprawdę dzieje. Moje doświadczenie wskazuje, że tak jest przy większości samouszkodzeń. Administracja odszyfrowuje jednak odpowiednie procedury i sekrety, w efekcie czego częściowo - ale niekoniecznie całkowicie - tracą one swoją przydatność. Z czasem pojawiają się też nowe warianty starych procedur (np. tak na przestrzeni kilkudziesięciu lat modyfikowano połyk). Sam byłem w stanie - dzięki połączeniu lekkich samouszkodzeń i symulacji oraz sfabrykowanych przez więziennych i wolnościowych lekarzy testów specjalistycznych — uzyskać wcześniejsze zwolnienie z powodu „złego stanu zdrowia”"13.

\section{Podsumowanie}

Interakcje społeczne nie znoszą próżni instytucjonalnej. Wszędzie tam, gdzie nieustrukturyzowane interakcje generują wysokie koszty transakcyjne lub pojawiają się potencjalne korzyści, decydenci tworzą nowe instytucje wykorzystujące wcześniej niezrealizowane zyski. Dlatego wysokie, a nawet potencjalnie śmiertelne koszty walki w więzieniu motywują powstawanie instytucji, które ograniczają przemoc lub wykorzystują zagrożenie przemocą. System kastowy, manipulacja, wiedza tajemna, koalicje i delegowanie władzy w znaczący sposób zmniejszają koszty transakcyjnie potencjalnie brutalnych konfrontacji.

Punktem wyjścia mojej analizy jest gra „Cykor” i jej warianty. W rzeczywistości w więzieniu rzadko dochodzi do sytuacji, które można by modelować, używając „Cykora”. Instytucje modyfikujące „Cykora” zmieniają parametry tej gry, ograniczając przemoc.

13 Z mojego doświadczenia wynika, że zdecydowana większość „ucieczek z więzienia” jest wynikiem umiejętnego udawania choroby i samouszkodzeń oraz pomocy lekarzy. Malownicze ucieczki fizyczne zdarzają się niezwykle rzadko i należy je włożyć między bajki hollywoodzkie. 
Przede wszystkim sortowanie więźniów na sztywnych i słabych obniża motywację do walki modelowanej przez „Cykora”. Jeśli obaj więźniowie mają podobną siłę i wiedzą, że przeciwnik będzie walczył na śmierć i życie, przystępowanie do walki jest nieracjonalne. Grypsujacy tak właśnie postrzegają swoich przeciwników - innych grypsujących. Z kolei sztywny więzień może spotkać się ze słabym. Gdy znana jest ich względna siła, sztywny może bezpiecznie wykorzystać groźbę agresji wobec słabszego, zwykle w przypadku drobnej kradzieży własności frajera lub seksualnego czy innego upokorzenia w przypadku cwela. Obaj gracze wiedzą, że ich pozycja w grze jest asymetryczna, a grypsujący jest gotowy walczyć. W równowadze frajer akceptuje ograniczoną eksploatację, a cwel zapewnia oczekiwane usługi bez zbędnej dodatkowej przemocy.

Przekształcenie „Cykora” w potencjalnie mniej brutalne gry wynika z istnienia subkultury, która podczas inicjacji przydziela więźniów do różnych kast. Pojedynki na bajerę, fałszywe walki i rozwiązywanie konfliktów zmieniają grę z potencjalnie kosztownymi konsekwencjami w łagodniejsze interakcje. Członkostwo w koalicji wzmacnia natomiast siłę obronną więźnia i zapewnia dodatkowe zabezpieczenie przed agresją poprzez zwiększenie kosztu ataku. Wreszcie, w przypadku wielu samouszkodzeń osadzony przekonuje prokuratora lub naczelnika więzienia o swojej desperacji i motywacji do wyboru potencjalnie śmiertelnej strategii (prowadzącej do obustronnie niekorzystnego wyniku podobnego do wzajemnej walki w "Cykorze”), podczas gdy w rzeczywistości zaangażowanie więźnia jest sfingowane.

Subkulturowe reduktory przemocy nie są ani doskonale skuteczne, ani perfekcyjnie wdrażane przez anioły o szlachetnych motywacjach. Gracze są okrutni i popełniają błędy. Ich rozumienie funkcjonowania instytucji społecznych, procedur prawnych i - szczególnie - ludzkiego ciała jest często boleśnie nieadekwatne. Niektóre procedury samouszkodzenia mogą mieć negatywne konsekwencje dla inicjatorów i można je uznać za spontaniczny porządek instytucjonalny o negatywnych konsekwencjach dla całej zbiorowości (Martin i Storr, 2008). Pomimo swoich niedoskonałości nieformalne instytucje tworzone przez więźniów potrafią znacząco ograniczyć przemoc. Bardziej precyzyjna analiza kosztów i korzyści jest utrudniona przez to, że więźniowie skrupulatnie chronią swoją tajną wiedzę i procedury ${ }^{14}$. Opisane przykłady instytucji sugerują jednak, że nieograniczona i bezmyślna przemoc w więzieniu jest bardziej wyjątkiem niż normą. Pojawienie się takiej formy przemocy wymagałoby wyjątkowej sytuacji instytucjonalnej próżni podobnej do sztucznie stworzonego więzienia w eksperymencie Zimbardo.

14 Na przykład wszystkie najważniejsze typy interakcji omawiane w tym artykule zostały po raz pierwszy poprawnie zidentyfikowane i opisane przez autora dzięki jego statusowi prawdziwego więźnia. 


\section{BIBLIOGRAFIA}

Anderson, T.L., McChesney, F.S. (1994). Raid or Trade? An Economic Model of Indian-White Relations. The Journal of Law and Economics, 37(1), 39-74.

Banyard, P. (2007). Tyranny and the Tyrant. Zimbardo's “The Lucifer Effect" Reviewed. The Psychologist, 20(8), 494-495.

D'Amico, D.J. (2015). Spontaneous Order. W: Boettke, P.J., Coyn, C. (red.), The Oxford Handbook of Austrian Economics (s. 115-142). New York, NJ: Oxford University Press.

Gambetta, D. (2011). Codes of the Underworld: How Criminals Communicate. Princeton: Princeton University Press.

Gambetta, D., Székely, Á. (2014). Signs and (Counter) Signals of Trustworthiness. Journal of Economic Behavior and Organization, 106 (October), 281-297.

Goffman, E. (1961). Asylums: Essays on the Social Situation of Mental Patients and Other Inmates. Toronto-New York, NY: Anchor Books.

Hall, J.C., Martin, A.G. (2011). Austrian Economics: Methodology, Concepts, and Implications for Economic Education. Journal of Economics and Finance Education, 10(2).

Hamill, H. (2018). The Hoods: Crime and Punishment in Belfast. Princeton, NJ: Princeton University Press.

Haney, C., Banks, C., Zimbardo, P. (1972). Interpersonal Dynamics in a Simulated Prison. Stanford, CA: Stanford University Department of Psychology.

Haslam, S.A., Reicher, S., Bavel, J.J.V. (2018). Rethinking the Nature of Cruelty: The Role of Identity Leadership in the Stanford Prison Experiment. Dostęp: https://psyarxiv.com/b7crx/

Haslam, S.A., Reicher, S.D. (2012). Contesting the "Nature" of Conformity: What Milgram and Zimbardo's Studies Really Show. PLoS Biology, 10(11), e1001426.

Hayek, F.A. ([1988] 1994). The Fatal Conceit: The Errors of Socialism (wydanie 1994). Chicago, IL: University of Chicago Press.

Kamiński, M.M., Gibbons, D.C. (1994). Prison Subculture in Poland. Crime and Delinquency, 40(1), 105-119.

Kaminski, M.M. (2003). Games Prisoners Play: Allocation of Social Roles in a Total Institution. Rationality and Society, 15(2), 188-217.

Kaminski, M.M. (2004a). Gry więźniów: Podział ról społecznych w instytucji totalnej. Studia Socjologiczne, 174(3), 93-122.

Kaminski, M.M. (2004b). Games Prisoners Play. Princeton, NJ: Princeton University Press.

Kamiński, M.M. (2006). Gry więzienne: Tragikomiczny świat polskiego więzienia. Warszawa: Oficyna Naukowa.

Kaminski, M.M. (2021). Games prisoners do not play: against the Hobbes-Zimbardo approach of unmitigated prison violence. Journal of Institutional Economics (w druku), 1-18.

Kaye, T. (reż.) (1998), American History X, New Line Cinema. Dostęp: 24 sierpnia 2020. http://www. imdb.com/title/tt0120586

Kekoshvili, V., Slade, G. (2020). Prisoner games children play: Youth socialization and criminal subcultures in the Republic of Georgia. Problems of Post-Communism, 67(3), 277-287. 
Loach, K. (reż.) (2002). Sweet Sixteen. Lions Gate Films. Dostęp 24 sierpnia 2020. https://www. imdb.com/title/tt0313670/?ref_=fn_al_tt_2.

Martin, N., Storr, V.H. (2008). On Perverse Emergent Orders. Studies in Emergent Order, 1(1), 73-91.

Miszewski, K. (2007). Uniwersytet więzienny. Studia Socjologiczne, 184(1), 163-171.

Miszewski, K. (2015). Zabójcy w więzieniu. Warszawa: Oficyna Naukowa.

Niesiołowski, S. (1989). Wysoki brzeg. Poznań: W Drodze.

Niewolski, K. (reż.) (2003). Symetria. Dostęp: 24 sierpnia 2020. https://en.wikipedia.org/w/index. php?title=Symmetry_(film)\&oldid=889546102

Pontecorvo, G. (reż.) (1966). La battaglia di Algeri. Dostęp: 24 sierpnia 2020. http://www.imdb.com/ title/tt0058946/

Reicher, S., Haslam, S.A. (2006). Rethinking the Psychology of Tyranny: The BBC Prison Study'. British Journal of Social Psychology, 45(1), 1-40.

Rider, R. (1993). War, Pillage, and Markets. Public Choice, 75(2), 149-156.

Searle, J.R. (2005). What is an institution?. Journal of institutional economics, 1(1), 1-22.

Skaperdas, S. (1992). Cooperation, Conflict, and Power in the Absence of Property Rights. The American Economic Review, 82(4), 720-739.

Skarbek, D. (2020). The Puzzle of Prison Order: Why Life Behind Bars Varies Around the World: Why Life Behind Bars Varies Around the World. Oxford-New York, NY: Oxford University Press.

Skarbek, D. (2014). The Social Order of the Underworld: How Prison Gangs Govern the American Penal System. Oxford-New York, NY: Oxford University Press.

Skarbek, D. (2016). Covenants without the Sword? Comparing Prison Self-Governance Globally. American Political Science Review, 110(4), 845-862.

Smith, J.M., Price, G.R. (1973). The Logic of Animal Conflict. Nature, 246(5427), 15.

Spicer, R.S., Miller, T.R. (2000). Suicide Acts in 8 States: Incidence and Case Fatality Rates by Demographics and Method. American Journal of Public Health, 90(12): 1885.

Symkovych, A. (2018). The "Inmate Code" in Flux: A Normative System and Extralegal Governance in a Ukrainian Prison. Current Sociology, 66(7): 1087-1105.

Székely, A., Gambetta, D. (2019). Fighting and Information: From Prison to the Lab, SocArXiv.

Tintinalli, J. (2015). Tintinallis Emergency Medicine: A Comprehensive Study Guide. New York, NY: McGraw-Hill Education.

Varese, F. (1998). The Society of the vory-v-zakone, 1930s-1950s. Cahiers Du Monde Russe, 39(4): 515-538.

Voigt, S. (2018). How to measure informal institutions. Journal of Institutional Economics, 14(1), 1-22.

Wojciechowski, R. (1981). Rok 1952. Krytyka, 12, 124-140.

Zimbardo, P.G. (2011). 'Lucifer Effect'. The Encyclopedia of Peace Psychology. Dostęp: 8 kwietnia 2020. https://doi.org/10.1002/9780470672532.wbepp149 